\title{
Party policy change. Exploring the limits of ideological flexibility in Belgium.
}

Dr. Nicolas Bouteca (Ghent University)

(Nicolas.Bouteca@ugent.be)

Prof. Carl Devos (Ghent University)

(Carl.Devos@ugent.be)

PSA Conference 2015

Sheffield, $30^{\text {th }}$ March $-1^{\text {st }}$ April

Party Politics II 


\begin{abstract}
Parties need to adapt their policy platforms in order to win elections, yet this is not without risk. Policy shifts can reduce credibility and foster intra-party conflicts. As a result, parties tend to proceed with caution when programmatic changes are made. In this article two risk reduction methods are formulated as hypotheses and investigated. First, we claim that parties will prefer making changes to the amount of attention issues get in a manifesto than to the positions they defend. Second, we argue that the amount of change is related to the ideological and electoral importance of the issue. In other words, we assume that parties are less likely to make positional changes on issues they own because this can possibly bring about loss in credibility and contradicts with the fact that politicians and party members are policy driven. These hypotheses are examined with new data gathered through the content analysis of the party manifestos of the Belgian Liberal party and the social-democratic party for elections held between 1961 and 2010. The article concludes that parties make smaller positional changes as opposed to changes in the issues they emphasize. Only weak evidence was found for the fact that the positional flexibility towards an issue correlates with the ideological and electoral importance of an issue.
\end{abstract}

\title{
Keywords
}

Ideology, party change, issue ownership, Belgium

\section{Introduction}

Party policy change appears to be one of the most intriguing issues in politics. In order to convince as many voters as possible, political leaders regularly adapt their policy platforms to a changing society with shifting needs and constraints (Mair, 1997:49; Budge 1994). Such programmatic changes usually draw considerable media attention, not least because the strategic considerations that lead to manifesto changes are mouth-watering for political journalists and the public they are writing for. This media frenzy probably explains why political scientists have taken great interest in mapping ideological changes (e.g. Budge et 
al., 2001) and explaining why parties change (e.g. Downs, 1957; Adams et al., 2004). However, how these changes are made remains far less researched (Meyer, 2013:15). This is striking because we may assume that ideological renewal is no improvisation but a very rational process that is not without risks (Downs, 1957; Klingemann and Volkens, 2002; Meyer, 2013; Tavits, 2007).

Hence, in this article we argue that parties tend to proceed with caution when they make changes to their manifestos. Firstly, we claim that parties differentiate between the issues they emphasize and the positions they defend, it is easier for them to make changes to the former than to the latter. This claim is based on earlier theoretical work of Harmel et al. (1995) and Janda et al. (1995), but has never been empirically tested. They assume that parties tend to be more flexible about the package of their manifesto, i.e. issues they emphasize than about the concrete positions they seek to defend because the latter is considered as far more risky.

Secondly, we argue that whether large policy shifts are made depends on the issue. We differentiate between issues that are ideologically as well as electorally paramount to a party on the one hand, and less important issues on the other hand. Parties are more likely to make ideological changes concerning issues that have less importance value. Given the automatic association of certain issues to certain parties by voters (Petrocik, 1996), parties will pursue stability on core issues.

Uncovering how ideological changes are made can enhance our knowledge of the importance of ideology for parties. It will, for instance, shed new light on how ideology relates to other strategic considerations, such as charismatic party leaders (Feld and Grofman, 1991; Groseclose, 2001), as a means to attract votes. Do parties handle their ideology with care, or is ideology merely of secondary importance in the competition with other parties? Thus, this article contributes to different areas of political research such as party competition and party change (Harmel and Janda, 1994; Appleton and Ward, 1997) and the broader decision-making process within political parties which has been identified as 
an under-researched topic in party politics (Van Haute \& Carty 2012). Besides, since relatively little work has been done on how parties change instead of why they change (Meyer, 2013:15), this article aims to fill this gap in literature.

This research draws on new manifesto data from the Belgian liberal and socialist party across half a century. Given the specific character of the research question, specialized codings were needed. Based on earlier research of Laver and Garry (2000), a fine-grained coding scheme was developed which enabled us to code on position and emphasis at the same time.

In the next section we first point out that there are risks attached to ideological changes. Afterwards, we provide the theoretical framework for the two claims that are made in this article. The first claim relates to the assumption that parties prefer to make changes to the package of their manifesto instead of to the content. The second claim is that the amount of change made to an issue is associated with the ideological and electoral importance of the issue. The following section focusses on the case selection and the coding process. Lastly, we empirically test our hypotheses and formulate the conclusions.

\section{Limited ideological flexibility}

Programmatic inertia is not an option in a changing society (Mair, 1997:49), let alone in the highly competitive environment of party politics. Given that parties' policy is one of the only factors that they can fully control, contrary to, for instance, the charisma of a party leader, parties will change their manifestos in order to influence their vote totals (Tavits, 2007). But programmatic changes will be only electorally rewarding if it is done the right way (Tavits, 2007:151).

Different scholars of party competition have emphasized that parties contemplate the policy changes they wish to carry out in order to stay credible. According to the followers of the salience theory, ideological flexibility is limited because parties stem from major cleavages, which brings along a certain programmatic reputation. In this sense, they are not free to change their manifestos whenever they wish in that this action can be very harmful for their reputation (Klingemann and Volkens, 2002:145; Meyer, 2013:10). Even Downs, who stated 
that "parties formulate policies in order to win elections rather than win elections in order to formulate policies" (1957:28), stressed that voters do not trust parties that frequently adopt policies that are inconsistent with its old ones (1957:109). Recent empirical research by Meyer (2013) confirmed these theoretical assumptions with the conclusion that policy shifts are risky. New positions can reduce credibility if they go against previous views or foster intra-party conflict if members form the impression that their interests are no longer pleased.

In this article it is stated that parties will try to constrain the risks that are involved with policy shifts by limiting positional shifts and shifts on the issues they own. These arguments are based on the recognition that manifestos are made up of a package and a content and that there exists a hierarchy of issues.

\section{Package vs. content}

The difference between the content and the package of a party manifesto was pointed out by Janda et al. (1995) and Harmel et al. (1995). This distinction can be traced back to two rival theories of party competition: the positional and the salience theory.

The positional theory of party competition goes back to Downs' (1957) proximity voting model, according to which voters and parties can be positioned on a spatial dimension. The assumption is that people will vote for the party that is closest to its own ideological position. This proximity model was challenged by the directional model of party competition (Rabinowitz and Macdonald, 1989). It denies the downsian assumption that the distance between the position of the voter and the position of a party is the decisive factor in voting behavior. Accordingly, the direction of the position is more important. Although a leftist party may be closer to the position of a right-wing voter than the right party, the voter will still prefer the right party to the left party. Despite this difference both models, i.e. the proximity and the directional model, essentially state that parties compete by presenting different positions.

This is fundamentally different from the salience theory of party competition that gained popularity in the 1980s. It states that parties compete "by emphasizing different policy priorities rather than by directly confronting each other on the same issues" (Budge and 
Bara, 2001:7). Party competition is thus not concerned with taking a pro or con position on every issue, but is linked with emphasizing those topics on which parties think they have a good reputation and ignoring other topics. Because there is only one thinkable position on every issue, emphasis equals position (Budge, 2001:82). Although this assumption has been recently refuted in empirical tests of the salience theory (Dolezal et al., 2013; Gemenis, 2013), the added value of the salience theory was the introduction of the idea that emphasis is an essential element in party competition.

The different views on how parties compete implies that the downsian and salience model of party competition also differ in relation to the way in which party changes occur. The former stresses that parties make positional changes (Downs, 1957), while the latter underlines that parties vary in the issues they emphasize (Budge and Bara, 2001:7). To some academics, both factors are deemed important for explaining programmatic changes (Laver \& Garry, 2000; Laver, 2001; Verstraete, 2002; Meguid, 2005). This idea to focus on both facets of ideology was also the belief that inspired Janda et al. (1995) and Harmel et al. (1995) to differentiate between the content and the package of a party manifesto.

The content (or substance) of a party manifesto refers to the actual positions on issues which provide a party with a certain identity. For instance, a party can support increases or reductions of social welfare payments. Or it could be in favor of high levels of taxation or feel the need to cut taxes. The package, on the other hand, results from the emphasis that parties place on particular issues in order to project an electorally interesting image. Socialdemocratic parties, for instance, have a good reputation as defenders of the social security system because they provide ample space in their manifestos for this issue. The same applies to conservative parties and taxes.

The distinction between package and content is considered relevant for the research of party change (Harmel et al., 1995:1). A party's position may remain stable between two manifestos, while the percentage of quasi-sentences devoted to that issue may vary substantially (Janda et al., 1995:193). The distinction between package and content is not a normative premise. Both are equally important for Harmel et al. (1995) and Janda et al. (1995), but they serve different purposes. The package and content of a manifesto appeal to different target groups of a party (Harmel et al., 1995:3). A party's image - the package - is 
important to seduce the volatile electorate that is interested in the broad outlines (e.g. who is best at solving certain problems) rather thanthe specific details of a party's ideology. The latter - the content - matters markedly to the grassroots support. This means that a party manifesto should combine an image that can attract many voters with an identity that can charm the party activists. As with consumer goods one buys in a store, the same product can be wrapped in many different ways. This means that parties not only have to determine a spatial position but also need to choose what issues they will emphasize in the manifesto.

Several researchers (Janda et al., 1995; Harmel et al., 1995; Klingemann et al., 1994:24) expect it to be easier for parties and less risky to adjust their package than their content. In this respect, Janda et al. (1995:178) state the following:

It seems reasonable to assume that, in general, packaging is more easily altered than the substance of the party's platform. Hypothetically, a party hoping to do better in the next election could avoid some of the infighting and the ultimate risk involved in changing its basic positions on issues, but still strategically downplay some issues that were emphasized in the last manifesto, while playing up others."

Furthermore, if the package of a manifesto appeals to the broad electorate instead of the party's rank and file, the increased electoral volatility in Western-European democracies (Pedersen, 1979; Caramani, 2006; Mair, 2006) will make it plausible that parties primarily change the package of their electoral message. We could assume that positions are left untouched in order to keep the grassroots support and that parties will start their quest for the volatile voter by changing the issues they emphasize.

In other words, we may expect that ideological renewal is, in the first place, a matter of changing the image, rather than shifting with the content. Parties tend to be more flexible on the issues they can emphasize than on the concrete positions they seek to defend. This generates a first hypothesis that is labelled the positions vs issues hypothesis (H1): parties are more flexible about issues than positions.

Hierarchy of issues 
The argument that some issues are probably more susceptible to change than others is based on the fact that for a political party, one issue is more important than the other (Klingemann et al., 1994; Petrocik, 1996). In other words, every party has a hierarchy of issues. First of all, there are electoral reasons for this hierarchy. According to the issueownership model (Petrocik, 1996), voters automatically identify parties with certain issues. This issue ownership can be better explained by surveying the origin of parties. Parties that were founded to represent the interests of a social class, 'own' the issues that are important for that class. By putting their problems first on the political agenda, parties automatically have an advantage over the other parties (Petrocik, 1990:5). Next to the origin of parties, the dynamics of political conflict regularly reinforce this issue ownership (Petrocik, 1996:828). By raising a certain issue in a political debate on TV, for instance, a politician can claim the ownership of that issue. The same holds true for parties that frequently emphasize an issue in their manifestos, or regularly put it on the parliamentary agenda and formulate legislative proposals for it (Walgrave et al., 2009:157). As a result, "such a party 'owns' an issue and has a greater likelihood of being regarded as particularly able to handle it." (Petrocik, 1990:6, cited in Maddens, 1994:97)

This means that party $A$ is seen as the best option to handle with problem $A$, and party $B$ as the best choice if problem $B$ has to be solved. In this respect, scholars traditionally refer to social-democratic parties as a defender of the social security while conservative parties are seen as the most credible party on the tax issue. As a result of this mechanism, parties conventionally place the issues that they own high on the agenda in election campaigns. "A candidate's campaign can be understood as a 'marketing' effort: the goal is to achieve a strategic advantage by making problems which reflect owned issues the programmatic meaning of the election and the criteria by which voters make their choice." (Pertocik, 1996:828). Put in another way, if a party succeeds in making the issue it 'owns' the main theme in the elections, then this party is surely well on the way to achieving an electoral victory (Budge and Farlie, 1983). For its opponents, the opposite is true: electoral chances will increase if an issue that another party owns is downplayed.

Based on the strategic importance of these 'owned' issues, we can assume that parties will deal with these themes with the greatest caution. This means that they will be wary of 
repudiating previous positions on these core issues or with the decision to downplay them in their party communication because too much flexibility would be pernicious for the credibility of a party on the issues it owns (Klingemann et al., 1994:24). Most people are guided by pragmatic and instrumental motivations when they cast their vote (Petrocik, 1996:830) and choose the party that is best placed to cope with a certain problem. Voters attribute ideological expectations to parties (Meyer, 2013:10) and as a result, noise in the communication on core issues could be electorally harmful, which means that parties do not have much space to make changes to these important topics. Too much flexibility about an issue would affect the perception that a party is the expert at solving that kind of problems (Volkens and Klingemann, 2002:145).

Based on the above, we can assume that from an electoral point of view, not all issues are equally important. Yet, there is also a behavioristic reason for this hierarchy: politicians are to some extent policy motivated (Wittman, 1983; Adams et al., 2004:185) and are probably not prepared to change any issue in order to win votes. Politicians are, without any doubt, not purely office driven. If politicians were pure office seekers, they would switch parties every time when they lost elections and become a member of the winning formation. Yet, this is not the case (Klingemann, 2004:23) in that politicians are also policy seekers for whom ideology and the realization of their program count. This entails stability and discourages ideological change. This programmatic inertia is also fueled by party activists who are usually ideological purists and have a restraining effect on party manifestos. According to the activist theory of party competition (Aldrich, 1983), the party on the ground can act as a brake on programmatic change.

Yet, this programmatic consistency has its limits in a changing society with shifting needs (Mair, 1997:49). Therefore, it sounds reasonable that parties, in their search for finding a balance between a policy and office seeking strategy, will choose to make ideological changes to less important issues in order to preserve what is really important. Party manifestos are, like ideologies, composed of a few central ideas and several -less importantperipheral concepts. According to Heywood (2003:14), these fringe concepts can be used in a flexible way without affecting the essence of an ideology. This means that, if ideological changes occur, we may expect that politicians prefer to make them to issues that do not lie 
at the heart of the party manifesto because that doesn't fundamentally change the goals of a party.

In brief, there are electoral and behaviouristic reasons to assume that not all issues have the same status and that some issues are more eligible for change than others. This leads to a second hypothesis called the hierarchy of issues hypothesis (H2): parties are more flexible on issues that are less important for the party and its voters.

\section{Methodology and data}

Researchers of party policy generally make use of the data collected by the Comparative Manifesto Project (CMP). This research group has quantitatively analyzed parties' election programs from more than 50 countries covering all free democratic elections since 1945 (Klingemann et al., 2006; Volkens et al., 2013). Despite being a rather interesting dataset, it does not completely fit this study because the CMP uses a coding scheme that is designed to code only on emphasis and has rather broad categories. For our research, specialized codings were required. First, we needed a method that enabled us to distinguish between position and emphasis. Second, the coding scheme has to be detailed enough to draw meaningful conclusions on the assumed hierarchy of issues. The scheme that Laver and Garry (2000) designed to code manifestos combines both objectives and served as the basis for our content analysis. Before we explain how this method works, we briefly outline our case selection.

\section{Case selection}

Since we did not make use of the traditional CMP data, party manifestos had to be recoded again. This was a fairly labour-intensive task that seriously limited the empirical ambitions of our research. For practical reasons the hypotheses were only tested on the basis of the party manifestos of the Belgian liberal party (Open VLD) and the social-democratic party (sp.a) with regard to socioeconomic issues in the period from 1961 to $2010^{i}$. By doing that, we have tried to create optimal research conditions, meaning that the cases were selected in order to make policy change highly observable. This will not lead to biased results because we are not interested in the amount of ideological change, but in the way that ideological 
change occurs. Hence within the limited practical possibilities of this research, the selected cases must assure us that there would be some empirical material to analyze. In other words, our sample had to contain a vast amount of changes.

Our analysis of the socialist and liberal manifestos started with the elections of 1961, because after that date parties became more catch-all. This is a process that goes hand-inhand with serious policy changes (Kircheimer, 1966), which is the phenomenon we concentrate on in this article. This 'catch-allisation' certainly applies to the Belgian socialist party, which was becoming an established governing party and started to behave in a more technocratic way by opting for a 'modern' socialism (Witte et al., 2009:279). The same goes for the Belgian liberal party, which started out as a cadre party but launched its first of many attempts to seduce a broader electorate in 1961 (Prevenier and Pareyn, 1989:332). Another reason to take 1961 as a starting point is that those elections followed the introduction of an important law for the economic recovery of Belgium. The strikes resulting from the implementation of this law are generally considered as the climax of the class struggle in Belgium. From then onwards, theoretically speaking, we can expect that both parties start to change their socio-economic policy proposals. The only drawback to taking this early start is that Belgian parties split along linguistic and territorial lines during our research period. Therefore, the parties under research were not completely identical in 1961 and 2010. The liberal party split up in 1974 and the socialist party in 1978. From these dates onwards, we therefore only considered the manifestos of the Flemish wings. Given that the Walloon socialism had always been more traditional than the Flemish one, we can expect to see large changes around 1978. Within the liberal party family there are less ideological differences between the north and the south of the country.

To answer our hypotheses, we only considered the socioeconomic policy proposals, in other words, the social and/or economic issues that belong to the traditional economic left-right dimension in the manifestos. They deal with the amount of state intervention in the economy, the budget, the relation between employers and employees and the desired level of equality. Of these issues, we chose to leave out post-materialistic statements on the environment or the rights of women, immigrants and other minority groups, since these matters belong to the socio-cultural dimension. The explanation for this focus on 
socioeconomic policy proposals is threefold. First, parties had always talked about socioeconomic issues in their party manifestos. The average percentage of text units, devoted to socio-economic issues in the 32 manifestos that were used for this research, was $54,1 \%$. Other issues, such as integration or the environment, had a more volatile character. Second, the traditional economic left-right-dimension is the most important divide in politics (Dalton, 1996; Lijphart, 1999; Caramani, 2004). Although it would be an over-simplification to reduce politics to a constant class struggle, socioeconomic issues are central in most political debates. Thirdly, these statements made up the core identity of both parties, as the socialdemocratic as well as the liberal party were created on the socio-economic dimension. This means that changes on this dimension can be considered as extra risky. It implies that they will not be random but the result of a well-considered decision.

\section{Measuring position and emphasis}

We needed a method that could facilitate us to distinguish between the content and the package of a manifesto to test our hypotheses. That is why the party manifestos were coded on salience and position at the same time. The entire manifesto was first split up into quasisentences using the CMP coding instructions (Volkens, 2002:3-4). In a second stage, it was decided which quasi-sentences could be identified as belonging to the economic left-right dimension ii. For this, we used the economy section ${ }^{\text {iii }}$ of the expert-coding scheme designed by Laver and Garry (2000) with a few adjustments to match with the definition of socioeconomic statements we gave above (see figure 1). On the one hand, some categories were left out because they contained issues belonging to the socio-cultural dimension (e.g. the category on environmental protection). On the other hand, we added some categories focusing on the relation between employers and employees and the system of the social dialogue. This coding scheme consisted of 43 different tripolar categories, which makes it far more detailed than the CMP scheme that tries to cover the full policy spectrum with 57 categories.

The scheme is hierarchically structured. At the highest level there are five branches, one of which deals with the relation between employers and employees and the four others relate 
to the ways in which the state can intervene in the economy: the state budget, the state ownership of industries and services, state regulation, and direct action by the state. Within the state budget there are categories on the use of public funds for education, housing, defence, police ${ }^{\mathrm{iv}}$ and so on. The fine-grained character of the coding scheme allowed us to easily distinguish socioeconomic statements from other statements. But above all, the detailed analysis enabled us to draw meaningful conclusions on the assumed hierarchy of issues.

INSERT FIGURE 1 HERE

After the socioeconomic quasi-sentences were separated from the other text units, they were assigned to the correct directional group of one of the 43 categories of the coding scheme. General statements were coded within the broad branches, while detailed quasisentences were allocated to the specific categories. In contrast with the CMP research, the categories were not unipolar but tripolar. Every category had a left, right and neutral counterpart. Left and right were considered as absolute categories that do not change over time. A statement was seen as 'left' when it insisted on state intervention, more equality between the rich and the poor or when it defended the interests of employees. When a statement highlighted less state intervention, more individual freedom in the socioeconomic field or the protection of the interests of entrepreneurs, it was seen as 'right'. Statements with no clear preference were coded as neutral, except if they were embedded in a paragraph that otherwise expressed a clear 'left' or 'right' position. In that case, a neutral quasi-sentence was coded by analogy with the rest of the paragraph (see the coding conventions of Laver and Garry, 2000:624).

All the manifestos were coded by a single coder. We were aware of the implications this hand coding of political texts can have for the reliability of our data (Mikhaylov et al., 2012). Especially as this manual coding of 32 manifestos would take several months, there was a real risk that similar quasi-sentences would be coded in a different way. Moreover, the main disadvantage of a fine-grained coding scheme is that vaguely phrased policy statements by 
parties might easily fall into several categories. Hence, to ensure the reliability of the coding process, checks were needed (Budge 2001:14). That is why a log was created in which less obvious coding decisions on what is considered as left, right or neutral were written down. This ensured that comparable quasi-sentences in the manifestos of 1961 and 2010 were coded in a similar way. Furthermore, of every coded statement, a record was kept in the form of the category code next to every quasi-sentence in the analyzed manifestos. This not only increased the transparency of the coding process, but also enabled us to make any adjustments in a second reading.

To determine the position (Ilr) of a party on a socioeconomic issue, we considered the ratio between left and right quasi-sentences on the issue. The number of right quasi-sentences with regard to the issue ( $I r)$ was divided by the sum of left and right text units conveying information on that socioeconomic issue. By taking together some or all quasi-sentences, the position on a cluster of issues or the entire left-right dimension could be measured. The result was a score between 0 (extreme left) and 100 (extreme right). If an issue receives a positional score of 50 , this means that the manifesto contained an equal number of right and left quasi-sentences on the issue. A score above 50 (= more than $50 \%$ of all quasi sentences are right quasi-sentences) means that a party is located on the right with regard to that issue. The opposite goes for a score below 50 (= more than $50 \%$ of all quasi-sentences are left quasi-sentences).

$$
I l r=\frac{I r}{I r+I l} \times 100
$$

Emphasis (Iemph) was measured as the sum of the left (Il), right (Ir) and neutral (In) quasi-sentences devoted to an issue or a cluster of issues, divided by the total amount of socio-economic quasi-sentences in the manifesto (Mtot).

$$
I e m p h=\frac{(I l+I n+I r)}{M t o t}
$$




\section{Results}

In this section we will assess how party policy change takes place. We first tested the positions vs issues hypothesis $(\mathbf{H} 1)$. We assume that parties are more flexible on issues than on positions when they change their manifestos.

Table 1 contains the ideological change that sp.a and Open VLD made in the period 19612010 on eight different domains: state ownership, state regulation, direct action by the state (e.g. state action on jobs), social security, other state expenditure (e.g. infrastructure, education), taxes, budget deficit and the relation between employers and employees. $A$ distinction was made between positional change and change in the amount of emphasis that was put on a socio-economic domain. The clusters of coding categories are based on the different branches of the coding scheme and are a priori judgments.

We conduct this domain-specific analysis because inspecting ideological change on the socio-economic dimension as a whole has its limits. In order to obtain a picture of the varying emphasis that was laid on socioeconomic issues, we could limit ourselves to a comparison between the percentage of socioeconomic quasi-sentences that a party writes down in its manifestos. But such an estimate is rather rough because a party can devote an equal amount of its successive programs to socioeconomic issues and yet change considerably if it discusses completely different types of socioeconomic issues. For example, that would be the case if a party only discussed social security in manifesto $A$ and only taxes in manifesto $B$. The percentage of socioeconomic issues would be the same in both cases, but one could scarcely assert that both manifestos are identical. That is why a more thorough analysis is needed. We do not aim to investigate the extent to which a party refers more or less to socioeconomic issues in its manifestos, but we are interested in the extent to which it discusses the same socioeconomic issues. The change in emphasis (emp) is calculated as the difference between the percentage of quasi-sentences that were devoted to a socio-economic domain in year $\mathrm{t}$ and year $\mathrm{t}+1$ and is expressed in percentage points. 
In order to gain a picture of the way that parties shift the content of their manifesto, positional change was used. As with the emphasis measure of party change we explained above, we did not limit ourselves to measuring the difference between the aggregate position on the socio-economic dimension in Year A versus Year B. This would be a rough approach of party change. For instance, it could underestimate the total amount of change, since positional changes on one domain of the socio-economic dimension can be offset by changes on another domain. In fact, if a party moved to the right on matters of social security but changed to the same amount in the opposite direction on taxes, aggregated scores would hide the considerable change that occurred between the two platforms. Positional change (p) was calculated as the difference between the position on a socioeconomic domain in year $\mathrm{t}$ and year $\mathrm{t}+1$ and is expressed in percentage points.

\section{TABLE 1, insert here}

In order to judge whether a party changes the package of its manifesto more easily than the content, we looked at the number of times that the emphasis put on a socio-economic domain changed in a large way, and compared this with that number of times that the parties took a large positional leap. Ideological change was considered as large when a party changed its position with 33 percent points $(=1 / 3$ of the possible positional change $)$ in between elections or spent 33 percent more or less quasi-sentences on one of the socioeconomic domains than in the average party manifesto $(=1 / 3$ of the possible change if we consider the average amount of emphasis on the issue) $)^{v}$. This ' 33 percent rule' is arbitrary but it facilitates the descriptive analysis because we work with two kinds of measures. If our case shows more positional movements that can be considered as large than large changes in the amount of quasi-sentences that are spent on a socioeconomic domain, the hypothesis is rejected.

In Table 1 we consider the programmatic changes of sp.a on taxes between 1971 and 1974 as an example. The position of sp.a between 1971 and 1974 changed with 85,7 percent points from 100 in 1971 (=100\% of the quasi sentences on taxes in the program were right 
quasi-sentences) to 14,3 in $1974(=14,3 \%$ of the quasi sentences on taxes in the program were right and $85,7 \%$ quasi-sentences were left). This is more than the 33 percent points change, which is considered as a large change. The change in emphasis is 4,9 percent point, which is more than $1 / 3(2,2$ percent points, see last line in table 1$)$ of the average amount of quasi-sentences spent on this issue in all the manifestos of sp.a between 1961 and 2010. This indicates that the change is considered large. Large changes are highlighted in grey in the table. An empty cell means that change could not be calculated, which ,for instance, is the case when a party only talks about an issue in a neutral sense. Under those conditions it is not possible to calculate a position. By extension it is also not possible to measure positional change between consecutive elections.

Based on Table 1, our first hypothesis could be confirmed: parties are more inclined to make changes to the issues they emphasize than to their positions. The programmatic movements of sp.a and Open VLD are mostly larger when we consider issue salience than when we look at the positions. Between 1961 and 2010 we analysed 238 changes in issue salience, of which 140 (59\%) can be considered large. The positional changes of both parties were far less frequently prominent. Only $33(15 \%)$ of the 220 positional changes we analysed were greater than 33 percent point. Hence, we can conclude that parties deal in a more flexible way with the package of their manifestos than with the content.

There seems to be a difference between both parties. Especially the liberal party shows ideological suppleness and changes positions and issue salience more radically than the social-democrats in between elections. In 64 percent of the cases Open VLD changed its issue salience with more than 33 percent of the average number of quasi-sentences that are spent on an issue, whereas sp.a only in 53 percent of the cases. The same is true for positional change: Open VLD makes a large change in 20 percent of the cases, sp.a only in 11 percent.

When comparing the different domains of the socio-economic dimension, we find that both parties are most fickle on the budget deficit. The amount of attention paid to this policy domain changes largely in 75 percent of the cases. Social security, on the other hand, seems to gain the most stable amount of attention. Only in 40 percent of the cases a large change could be detected. From a positional point of view, sp.a and Open VLD showed most 
flexibility in the domain of the regulation of the economy, while positions on state ownership were very stable. In the first domain we find that 13 percent of the changes can be considered as large, while in the latter domain large changes are restricted to only 5 percent of the changes.

Hierarchy of issues

According to hypothesis two (H2), ideological movement is mainly the result of positional changes on issues that are less important for a party ${ }^{\text {vi }}$. Table 2 and 3 show the average positional change on the different categories or issues of the coding scheme ${ }^{\text {vii }}$.

TABLE 2 and 3, insert here

The average positional change $(\bar{p})$ was computed by making the sum of all changes $(p)$ (maximal change is 100 , minimal change is zero) in between elections on an issue. This was divided by the number of consecutive election pairs $(e)$ in which positional changes could be calculated.

$$
\begin{gathered}
\overline{p_{i}}=\frac{\sum_{i=1}^{n} p_{i}}{\sum_{i=1}^{n} e_{i}} \\
\text { where } \frac{p_{i}=p_{1}+p_{2}+p_{3} \ldots p_{n}}{e_{i}=e_{1}+e_{2}+e_{3} \ldots e_{n}}
\end{gathered}
$$

For some issues, a positional score could be calculated every election. As a result, the sum of all changes was divided by 15 (i.e. the amount of consecutive elections in this research). For less salient issues, the number of positional changes that could be used to calculate the average change was lower. Since the amount of observation can affect the reliability of the estimates, confidence intervals were reproduced (see appendix 1 and 2). 
Table 2 and 3 show that not all issues are equally susceptible to change. With reference to some issues both parties never changed positions (issues with a score of 0.00 in tables 2 and 3), while positions were changed every election regarding other issues (e.g. Open VLD on the regulation of the financial sector). With regard to hypothesis two it is remarkable that the liberal party firmly holds on to its position on some tax issues while it changes positions quite frequently on social security issues. Social-democrats, in contrast, are actually flexible on tax issues but relatively rarely changed their opinion on social security issues. Earlier research on issue-ownership in Belgium has shown that liberals own the tax issue while social security is owned by the social-democrats (Walgrave and De Swert, 2007:44). Hence the positional flexibility towards an issue seems to correlate with the ideological and electoral importance of an issue for a party. Furthermore, it is interesting to see that within the top five issues that liberals do not change, there are three issues (payroll taxes, sales taxes and budget deficit) that are within the top five issues that social-democrats change radically. This could be an indication that parties are not inclined to change positions on issues that are important to them, but have less problems with switching positions on issues that are only ideologically important to their competitors.

Next to the descriptive analysis above, hypothesis two was also quantitatively tested. Hence, the concept 'important issues' had to be operationalized. The importance of an issue was determined by its salience during the period 1961-2010. We assume that the more an issue was mentioned in the manifestos of the parties of this research, the more electoral (Walgrave and De Swert, 2007) and ideological importance this issue held for a party. Table 4 and 5 show the number of quasi-sentences that were spent on the different categories of the coding scheme. ${ }^{\text {viii }}$ We found that the liberal party spent most of its quasi-sentences on 'state action for jobs', while 'health care' is the most important social-democratic issue. For both parties, Pearson correlation coefficients were calculated for the relationships between the number of quasi-sentences spent on the different issues and the average change on these issues. In both cases importance correlates negatively with party change, meaning that the more important an issue is, the less susceptible it is to change. Although this corresponds with what we expected, the correlations are not strong enough to firmly support hypothesis two: $-0,041$ (sig 0,827) for VLD and -0,196 for sp.a (sig 0,281). However, the weak correlations do not mean that the opposite is true and that parties frequently 
change positions on important issues. It means that the expected negative correlation is weakened by a few issues that are very important and on which parties are regularly changing positions. It is striking that both sp.a and Open VLD emphasize pensions, jobs and health care to a great extent and often change positions on these issues. This could mean that the 'true' ideological core is somewhat pushed to the back by issues that are important for the median voter who is less sensitive to positional switches than the party activists who are ideological purists.

Table 4 and 5, insert here

\section{Conclusions}

In this article, we have considered party policy change through the analyses of the socioeconomic sections of the party manifestos of Belgian liberals and social-democrats between 1961 and 2010. We did not make use of the well-known CMP data, but collected new data to test our hypotheses. In practice, this means that we drew upon a more fine-grained coding scheme than the CMP-scheme, and consequently coded the manifestos on both position and emphasis at the same time. There are two reasons accounting for why we obtained these alternative data. First, this methodology allowed us to test the robustness of the assumption that parties are more flexible on issues than on positions when they make programmatic changes. Until now, this was not yet tested. Second, we needed positional estimates for all issues of the coding scheme. The alternative data enabled us to test whether parties are more likely to make positional changes to less important issues than to important ones.

From an empirical standpoint, our findings have contributed to enriching the literature on party policy change and especially the under-studied domain of how this change occurs. The assumption that parties change the 'package' of their electoral message more easily than 
their 'content' was confirmed in our case. In between elections Open VLD and sp.a show more flexibility about the issues they emphasize than on the positions they defend. These results lend support to the strategic decision-making on party policy within parties that Janda et. al. (1995) suggest. An idea that was further developed in this article. Parties are forced to make adjustments to their manifesto by the changing social context, but it seems reasonable to hold on to their positions as much as possible and primarily change the issues they emphasize. By holding on to their positions, parties can avoid internal struggles, while trying to woo the volatile electorate by playing up popular issues and downplaying unpopular ones.

To maximize success in elections, party policy change must be credible (Meyer 2013) to the broad electorate and acceptable for the rank-and-file. That is why it was claimed in this article that parties will not make substantial changes to issues they own. The in-depth analysis of the positional changes for every issue of the coding scheme shows that ideological flexibility varies depending on the issue. Parties seem to have issues that are 'untouchable' and never change, but we only found weak evidence for the fact that the positional flexibility towards an issue correlates with the ideological and electoral importance of an issue for a party. Given that the correlations are weak, we cannot firmly conclude that parties tend to be less flexible about important issues and avoid risks by letting the positions of owned issues untouched.

Due to the limited number of parties analyzed, the results presented here may slightly fall short of offering abundant evidence. Thus, further research needs to include more cases. The greater number of parties will allow clear differentiation between the types of parties. For instance, new parties that have not developed links with several interest groups could probably be more susceptible to change than the old parties that have some long-standing relations to maintain. An analysis of the possible difference between party families will be an especially desirable and fruitful avenue for further research. Our analysis shows that party policy changes are much greater within the rightist Open VLD than the leftist sp.a. This confirms the assumption that left-wing parties are ideologically less flexible than right-wing parties (Przeworski and Sprague, 1986). 
In conclusion, we acknowledge that our research may have some methodological limitations. Especially the coding process can be improved. Several 'quality checks' were performed in order to improve the reliability of the coding process, but there is discussion on the added value of such checks (Gemenis 2013). Inter-coder reliability should be checked; therefore, a second coder is needed. Nonetheless, we are convinced that the in-depth analysis presented here is an enrichment to the existing research on party policy change.

\section{References}

Adams, J., Clark, M., Ezrow, L. and Glasgow, G. (2004). Understanding Change and Stability in Party Ideologies. Do Parties Respond to Public Opinion or to Past Election Results? British Journal of Political Science 34: 589-610.

Aldrich, J. (1983) A Downsian Spatial Model with Party Activists. American Political Science Review 77: 974-990.

Appleton, A., \& Ward, D. (1997). Party Response to Environmental Change. Party Politics 3 (3): 341-362

Budge, I. (1994) A New Spatial Theory of party Competition: Uncertainty, Ideology and Policy Equilibria Viewed Comparatively and Temporally. British Journal of Political Science 24: 443-467.

Budge, I. and Farlie, D. (1983) Explaining and predicting elections. Issue effects and party strategies in twenty-three democracies. Londen: George Allen \& Unwin.

Budge, I. and Bara, J. (2001) Manifesto-Based Research: a Critical Review. In: I. Budge, H-D. Klingemann, A. Volkens, J. Bara and E. Tanenbaum (eds.) Mapping Policy Preferences. Estimates for Parties, Electors and Governments 1945-1998. New York: Oxford University press, pp. 20-74.

Budge, I. Klingemann, H-D. Volkens, A. Bara, J. and Tanenbaum E. (2001) Mapping policy preferences. Estimates for parties, electors and governments 1945-1998. New York: Oxford University press.

Caramani, D. (2004) The Nationalization of Politics: The Formation of National Electorates and Party Systems in Western Europe. Cambridge: Cambridge University Press.

Caramani, D. (2006) Is there a European Electorate and What Does It Look Like? Evidence from Electoral Volatility Measures, 1976-2004. West European Politics 29: 1-27.

Dalton, R. (1996) Political Cleavages, Issues, and Electoral Change. In: L. LeDuc, R. Niemi and P. Norris (eds.) Comparing Democracies: Elections and Voting in Global Perspective. Thousand Oaks: Sage Publications, pp. 319-342. 
Dolezal, M., Ennser-Jedenastik, L., Muller, W. and Winkler, A.-K. (2013) How Parties Compete for Votes: A Test of Saliency Theory. European Journal of Political Research.

Downs, A. (1957) An Economic Theory of Democracy. New York: Harper \& Row.

Enelow, J. and Hinich, M (1984) The Spatial Theory of Voting. Cambridge: Cambridge University Press.

Feld, S. and Grofman, B. (1991) Incumbency advantage, voter loyalty and the benefit of the doubt. Journal of Theoretical Politics 2: 115-137.

Groseclose, T. (2001) A Model of Candidate Location When One Candidate Has a Valence Advantage. American Journal of Political Science 45: 862-886.

Gemenis, K. (2013). What to do (and not to do) with the Comparative Manifestos Project data. Political Studies, 61(S1): 23-43.

Harmel, R. and Janda, K. (1994) An Integrated Theory of Party Goals and Party Change. Journal of Theoretical Politics 6: 259-287.

Harmel, R., Tan A., Janda, K. and Smith, J. (1995) Substance vs. Packaging: An Emperical Analysis of Parties' Issue Profiles Paper presented at the Annual Meeting of the American Political Science Association; September, Chicago, United States.

Heywood, A. (2003) Political Ideologies. An Introduction (Third edition). New York: Palgrave.

Janda, K., Harmel, R., Edens, C. and Goff, G. (1995) Changes in party identity. Evidence from party manifestos. Party Politics 1: 171-196.

Kirchheimer, O. (1966) The Transformation of the Western European Party Systems. In J. LaPalombara and M. Weiner (eds.) Political Parties and Political Development. Princeton: Princeton University Press, pp. 177-200.

Klingemann, H.D., Hofferbert, R. and Budge, I. (1994) Parties, policies, and democracy. Boulder: Westview Press.

Klingemann, H-D., Volkens, A., Bara, J., Budge, I. and McDonald, M. (2006). Mapping Policy Preferences II: Estimates for Parties, Electors, and Governments in Eastern Europe, the European Union and the OECD, 1990-2003. Oxford: Oxford University Press.

Laver, M. and Garry, J. (2000) Estimating Policy Positions from Political Texts. American Journal of Political Science 44: 619-634.

Laver, M. (2001) Position and Salience in the Policies of Political Actors. In M. Laver (ed.) Estimating the Policy Position of Political Actors. London: Routledge, pp 66-75.

Lijphart, A. (1999) Patterns of Democracy. New Haven: Yale University Press. 
Maddens, B. (1994) Kiesgedrag en Partijstrategie. De Samenhang Tussen de Beleidsmatige Profilering van de Partijen en het Kiesgedrag van de Vlamingen op 24 november 1991. PhD thesis, KULeuven, Leuven.

Mair, P. (1997) Party System Change. Oxford: Oxford University Press.

Mair, P. (2006) Polity-Scepticism, Party Failings, and the challenge to European Democracy (Uhlenbeck Lecture 24). Wassenaar: Nias.

Meguid, B. (2005) Competition Between Unequals: The Role of Mainstream Party Strategy in Niche Party Succes. American Political Science Review 99: 347-359.

Meyer, T. (2013) Constraints on Party Policy Change. Essex: ECPR-press.

Mikhaylov, S., Laver, M. and Benoit, K. (2012) Coder Reliability and Misclassification in the Human Coding of Party Manifestos. Political Analysis 20: 78-91.

Pedersen, M. (1997) The Dynamics of European Party Systems: Changing Patterns of Electoral Volatility. European Journal of Political Research 1: 1-26.

Petrocik, J. (1990). The Theory of Issue-Ownership. Issues, Agendas, and Electoral Coalitions in the 1988 Election. unpublished paper UCLA.

Petrocik, J. (1996) Issue Ownership in Presidential Elections, with a 1980 Case Study. American Journal of Political Science 40: 825-850.

Prevenier, W. and Pareyn, L. (1989) De Oprichting van de PVV/PLP en Haar Gevolgen: 1958-1969. In A. Verhulst and H. Hasquin (eds.) Het Liberalisme in België. Tweehonderd Jaar Geschiedenis. Brussels: Uitgeverij Delta, pp. 331-340.

Przeworski, A. and Sprague, J. (1986) Paper Stones: A History of Electoral Socialism. Chicago: University Press of Chicago.

Rabinowitz, G. and Macdonald, S. (1989) A Directional Theory of Issue Voting. The American Political Science Review 83: 93-121.

Tavits, M. (2007). Principle vs. Pragmatism: Policy Shifts and Political Competition. American Journal of Political Science 51: 151-165.

van Haute, E. and Carty, K. (2012) Ideological Misfits: A Distinctive Class of Party Members. Party Politics 18: 885-895.

Verstraete, T. (2002) Het janusgezicht van partijvernieuwingen: What you see is not what you get! Een analyse van het verschil tussen imago en identiteit bij politieke partijen. In: A. Van den Brande (ed.), Identiteiten: functies en disfuncties. Ghent: Academia Press, pp.144-182.

Volkens, A. (2002) Manifesto Coding Instructions (Second Revised Edition). http://skylla.wzberlin.de/pdf/2002/iii02-201.pdf 
Volkens, A. and Klingemann, H-D. (2002) Parties, Ideologies and Issues. Stability and Change in Fifteen European Party Systems: 1945-1998. In K. Luther and F. Muller-Rommel (eds.), Political Parties in the New Europe. New-York: Oxford University Press, pp. 143-167.

Volkens, A., Lacewell, O., Lehmann, P., Regel, S., Schultze, H. and Werner, A. (2013) The Manifesto Data Collection. Manifesto Project (MRG/CMP/MARPOR), Berlin: Wissenschaftszentrum Berlin für Sozialforschung (WZB).

Walgrave, S. and De Swert, K. (2007) Where Does Issue Ownership Come From? From the Party or from the Media? Issue-party Identifications in Belgium, 1991-2005. The Harvard International Journal of Press/Politics 12: 37-67.

Walgrave, S., Lefevre, J. and Nuytemans, M. (2009) Issue Ownership Stability and Change: How Political Parties Claim and Maintain Issues Through Media Appearances. Political Communication 26:153-172.

Witte, E, Craeybeckx, J. and Meynen, A. (2009) Political history of Belgium from 1830 onwards. Brussels: VUB University Press.

Wittman, D. (1983) Candidate motivation: a synthesis of alternatives. American Political Science Review 77: 142-157.

\footnotetext{
${ }^{\mathrm{i}}$ Given that short manifestos (those under 150 quasi-sentences) could have important implications (Budge et al., 2001, Klingemann et al., 2006) for the reliability of the estimates, we add the minimal (open VLD 1961: 114 quasi-sentences), maximal (sp.a 1991: 3049 quasi-sentences) and average (817 quasi-sentences) length of the socio-economic parts of the manifestos that were used in this research.

ii The total number of quasi-sentences in the manifestos of the liberal and social-democratic party between 1961 and 2010 was 26.128 , of which 13.035 were identified as socioeconomic.

iii The original coding scheme of Laver and Garry (2000) has over 300 categories and covers four policy areas: the role of the state in the economy, the organization of the political system, the role of the state in society and the role of the state in external relations.

${ }^{\text {iv }}$ A category such as police may seem odd to include, but it concerns statements directly supporting increased or decreased financial spending on the police. All other statements supporting the work of police (e.g. police should be tougher on small crimes) are not considered as socio-economic policy proposals. The same applies to defence and culture and sport.

${ }^{v}$ The average percent of quasi-sentences that a party spent on a socioeconomic domain in all the manifestos between 1961 and 2010.

${ }^{v i}$ This hypothesis is only tested for positional changes (the content) and not for changes in emphasis (the package). The main purpose of this paper is to get an idea of how parties try to avoid risks when they make changes to their manifesto. The difference made between package (emphasis) and content (position) was made in order to test hypothesis one. The debate on the difference between position and emphasis an sich is not the main focus of this research. Furthermore it is not possible to test hypothesis two with our data.

vii In both tables, five issues of the coding scheme were left out because it was impossible to compute an average change. This does not mean that these categories of the coding scheme stayed empty for the whole period of our research. But in order to compute change, we needed to have a positional score of a party on an issue for at least two elections on a row. This was not the case for five issues.

viii The general categories on taxes, social security, regulation, spending, policy towards workers and stateintervention were left out because this are broad categories. The detailed budgetary categories on money supply and public borrowing were also left out.
} 
Figure 1: Section of adjusted coding scheme (left categories on taxes)

\section{2 +STATE+/Budget/Taxes}

Increase taxes

(General statements supporting the need to increase taxation, which do not belong in any of the somewhat more specific categories 11121, 11122, 11123, 11124. Includes need to defend current taxation levels against demands for taxation reduction, the need to fight fiscal fraude and statements supporting the idea of taxation as a mechanism of re-allocating)

\section{$11121+$ STATE+/Budget/Taxes/Income}

(Income taxes, support increases or defend levels against demands for reduction)

$$
11122+\text { STATE+/Budget/Taxes/Payroll }
$$

(Payroll taxes, support increases or defend levels against demands for reduction)

$$
11123 \text { +STATE+/Budget/Taxes/Company }
$$

(Taxes on company profits, support increases or defend levels against demands for reduction)

$$
11124+\text { +STATE+/Budget/Taxes/Sales }
$$

(VAT or other sales taxes, support increases or defend levels against demands for reduction)

$$
11125+\text { STATE+/Budget/Taxes/Capital }
$$


Table 1: Ideological change (position and emphasis) of sp.a and Open VLD (1961-2010)

\begin{tabular}{|c|c|c|c|c|c|c|c|c|c|c|c|c|c|c|c|c|}
\hline & \multicolumn{4}{|c|}{ TAXES } & \multicolumn{4}{|c|}{ SOCIAL SECURITY } & \multicolumn{4}{|c|}{ REGULATION } & \multicolumn{4}{|c|}{ EMPLOYER/EMPLOYEE } \\
\hline & \multicolumn{2}{|c|}{ Open VLD } & \multicolumn{2}{|c|}{ sp.a } & \multicolumn{2}{|c|}{ Open VLD } & \multicolumn{2}{|c|}{ sp.a } & \multicolumn{2}{|c|}{ Open VLD } & \multicolumn{2}{|c|}{ sp.a } & \multicolumn{2}{|c|}{ Open VLD } & \multicolumn{2}{|c|}{ sp.a } \\
\hline & emp & $\mathrm{p}$ & emp & $p$ & emp & $p$ & emp & $p$ & emp & $p$ & emp & $p$ & emp & $p$ & e & $\mathrm{p}$ \\
\hline $1-65$ & 13,8 & & 0,7 & 26,7 &, 5 & 19,6 & 57 & 3,1 & 2,1 & 61,6 & 1,3 & 7,5 & & & 0,5 & 0,0 \\
\hline $5-68$ & & 0,0 & 2,9 & 26,7 & 6,4 & 6,9 & 7,0 & & ,3 & 11,2 & 8 & 7,5 & & 5,2 & 10,2 & 0,0 \\
\hline -'71 & & 0,0 & 2, & 33,4 & 0,1 & 9,7 & 6,0 & & & & 4 & & & & 10,6 & 0, \\
\hline -'74 & & 14,3 & 4,9 & 85,7 & 11,5 & 22,5 & 14,6 & 0,0 & 5,9 & & 8,3 & 0,0 & 0 & & 2,5 & 0,0 \\
\hline 4-'77 & 0,5 & 11,5 & 1,9 & 7,9 & 11,6 & 26,7 & 9,4 & 3,2 & 4,2 & & ,4 & 0,0 & & & 7,9 & 0,0 \\
\hline 7-'78 & & & & 25,8 & 10,2 & & & & & & 2,4 & & & & 3,1 & 0,0 \\
\hline 3-'81 & 10,1 & 2,7 & 2,3 & 27,7 & 8,6 & 65,7 & 1, & 2,6 & 6 & 71,4 & 3,9 & 9,8 & 6 & 100,0 & 2,1 & 2,4 \\
\hline$-' 85$ & 1,8 & 3,8 & 0,6 & 9,2 & 5,0 & & 4 & & & 10,0 & & & & & 6,2 & 1,6 \\
\hline -'87 & 10, & 1,6 & 1,4 & 33 & 0,5 & 27,9 & 4,8 & 3 & 0 & 10,0 & 8,7 & 1,8 & 10,0 & & 4,6 & 0,8 \\
\hline -'91 & & 6,8 & 0,1 & 0,5 & 0,3 & 7,8 & & & & 0,0 & 3,3 & 10,0 & & & 5,3 & 1,0 \\
\hline -'95 & 2 & 9,0 & 1,6 & & & 16,4 & 10,0 & & & 33,4 & 3,9 & 10,0 & & & 1,9 & 1,0 \\
\hline 95-'99 & 5,1 & 5,7 & 3,8 & 19,1 & 4,1 & 55,6 & 14,2 & 1,7 & 0,2 & 16,7 & 1,9 & 0,0 & 7 & & 1,1 & 4,8 \\
\hline 9-'03 & $16, \varepsilon$ & 5,7 & 5,9 & 21,1 & 12,8 & 25,7 & 5,6 & & & 50,0 & ,4 & 50,0 & & & 0,6 & 0,6 \\
\hline 03-'07 & 18,3 & 7,3 & 3,8 & 6,1 & 0,2 & 1,4 & 4,6 & 0,7 & & 29,4 & 1,4 & 50,0 & & & 0,2 & 1,9 \\
\hline 07-'10 & 2,2 & 11,3 & 11,7 & 5,8 & 5,8 & 40,4 & 10,9 & 12,2 & 0,3 & 50,6 & 10,5 & 0,0 & 6,1 & 3,8 & 2,5 & 2,3 \\
\hline 1/3-rule & 4,7 & & 2,2 & & 7,7 & & 9,0 & & 1,1 & & 2,5 & & 3,2 & & 3,6 & \\
\hline
\end{tabular}




\begin{tabular}{|c|c|c|c|c|c|c|c|c|c|c|c|c|c|c|c|c|}
\hline & \multicolumn{4}{|c|}{ OTHER EXPENDITURE } & \multicolumn{4}{|c|}{ BUDGET DEFICIT } & \multicolumn{4}{|c|}{ OWNERSHIP } & \multicolumn{4}{|c|}{ STATE ACTION } \\
\hline & \multicolumn{2}{|c|}{ Open VLD } & \multicolumn{2}{|c|}{ sp.a } & \multicolumn{2}{|c|}{ Open VLD } & \multicolumn{2}{|c|}{ sp.a } & \multicolumn{2}{|c|}{ Open VLD } & \multicolumn{2}{|c|}{ sp.a } & \multicolumn{2}{|c|}{ Open VLD } & \multicolumn{2}{|c|}{ sp.a } \\
\hline & & $p$ & emp & $\mathrm{p}$ & emp & $\mathrm{p}$ & emp & $\mathrm{p}$ & emp & $\mathrm{p}$ & emp & $\mathrm{p}$ & emp & $\mathrm{p}$ & emp & $\mathrm{p}$ \\
\hline 1-'65 & 30,0 & 39,6 & 0,2 & 10,2 & 0,1 & 0,0 & & & & & 3,1 & & 0,2 & & 2,7 & 0,0 \\
\hline 5-'68 & 16,7 & 1,4 & 0,6 & 1,5 & 6,4 & 0,0 & & & 4,1 & & 5,0 & & 0,8 & 1,7 & ,2 & 0,0 \\
\hline 3-'71 & 6,2 & 29,8 & 8,0 & 14,6 & 6,3 & 0,0 & 2,8 & 0,0 & 1,0 & & 3,4 & & 5,2 & 18,8 & 2 & 0,0 \\
\hline 71-'74 &, 0 & 5,8 & 6,1 & 17,7 & 1,6 & 0,0 & 4,2 & & 5,3 & 0,0 & 4,6 & 0,0 & 5,5 & & 0 & 50,0 \\
\hline 74-'77 & , & 21,7 & 14,0 & 9,8 & 1,8 & 0,0 & 0,4 & & 6,3 & & 0,3 & 0,0 & 9,4 & 4 & 2,0 & 50,0 \\
\hline -'78 & 3 & 3,3 & 0 & 2,6 & & 0 & 0,9 & 25,0 & & & 4,6 & 18,2 & 9,6 & & ,5 & 0 \\
\hline 3-'81 & 10,6 & 55,1 & 8,8 & 18,8 & 10,7 & 0,0 & 0,4 & 41,7 & 1,9 & & 1,3 & 18,2 & 9,6 & 48,9 & 4,4 & 1,3 \\
\hline -'8 & & & & 14,3 & & & 1,8 & & & 0,0 & & & ,5 & & 4 & ,3 \\
\hline -'87 & 5 & 9,8 & 1,5 & 3,1 & 5,0 & 0,0 & 0,1 & 26,4 & & 0,0 & 0,9 & 0,0 & 5,1 & 23,2 & 6,7 & 3,4 \\
\hline -'91 & & 23,2 & & 2,0 & 3 & & 1,4 & & & 6,5 & 1,2 & 15,4 & 3,3 & & 4,4 & 0,2 \\
\hline כת & & 3,2 & 1,8 & 2,4 & 0,0 & & 1,6 & 18,8 & 4,8 & 0,2 & 1,6 & 15,4 & 11,6 & & 3,5 & 3,6 \\
\hline 95-'99 & 5,0 & 23,1 & 11,9 & 8,2 & 3,6 & 0,0 & 1,9 & 0,0 & 8,3 & 11,4 & 0,3 & & 1,1 & 59,6 & 3,7 & 0,0 \\
\hline -'03 & 14,2 & 17,2 & & 4,6 & 2,4 & 0,0 & 1,5 & 0,0 & 4,5 & & 1,0 & & 10,4 & 15,0 & 10,7 & 27,8 \\
\hline 3-'07 & 4,0 & 2 & 9 & 2,1 & 2 & 0, & 0,0 & 75,0 & 1,1 & & 0,2 & 0,0 & 6,2 & 1,9 & 14,6 & 26,5 \\
\hline 07-'10 & 3, & 72,3 & 1,1 & 6,7 & 4,2 & 0,0 & 0,2 & 75,0 & 0,2 & 40,0 & 0,5 & 0,0 & 2,7 & 11,9 & 8,9 & 2,0 \\
\hline 1/3-rule & 5,2 & & 6,0 & & 1,2 & & 0,6 & & 1,1 & & 0,9 & & 3,0 & & 4,2 & \\
\hline
\end{tabular}


Tables 2 and 3: Average positional change between elections per issue for sp.a and Open VLD (19612010) (maximum = 100).

\begin{tabular}{|c|c|}
\hline Category & sp.a \\
\hline Science \& technology & 0,0 \\
\hline Housing (general) & 0,0 \\
\hline Housing: social & 0,0 \\
\hline Housing: private & 0,0 \\
\hline Social security (general) & 0,0 \\
\hline Child support & 0,0 \\
\hline Social security (other) & 0,0 \\
\hline Regulation (general) & 0,0 \\
\hline Regulation business \& industry & 0,0 \\
\hline State action neocorporatism & 0,0 \\
\hline Labour organizations & 0,0 \\
\hline Works council & 0,0 \\
\hline Work-family balance & 0,5 \\
\hline State action jobs & 0,9 \\
\hline Unemployment & 1,5 \\
\hline Policy towards workers (general) & 1,5 \\
\hline Public ownership & 3,1 \\
\hline Transport & 3,4 \\
\hline Pension & 4,2 \\
\hline Regulation prices & 4,6 \\
\hline Taxes on capital gains & 5,0 \\
\hline Infrastructure & 7,0 \\
\hline Health care & 7,6 \\
\hline Education \& training & 8,0 \\
\hline State action (other) & 8,3 \\
\hline Taxes on company profits & 9,8 \\
\hline Defence & 9,8 \\
\hline Regulation financial sector & 12,0 \\
\hline State intervention (general) & 15,6 \\
\hline Culture \& sport & 17,8 \\
\hline State action consumer & 22,5 \\
\hline Income taxes & 24,2 \\
\hline Spending (general) & 25,0 \\
\hline Taxes (general) & 29,7 \\
\hline Police & 30,0 \\
\hline Budget deficit & 30,6 \\
\hline Payroll taxes & 32,8 \\
\hline Regulation trade & 55,8 \\
\hline Sales taxes & 94,4 \\
\hline
\end{tabular}

\begin{tabular}{|lr|}
\hline Category & Open VLD \\
\hline Payroll taxes & 0,0 \\
\hline Sales taxes & 0,0 \\
\hline Taxes on capital gains & 0,0 \\
\hline Budget deficit & 0,0 \\
\hline State action neocorporatism & 0,0 \\
\hline Works council & 0,0 \\
\hline Housing: private & 0,8 \\
\hline Taxes on company profits & 1,4 \\
\hline Income taxes & 5,9 \\
\hline Public ownership & 7,3 \\
\hline State intervention (general) & 8,1 \\
\hline Regulation trade & 9,5 \\
\hline Child support & 10,7 \\
\hline Social security (other) & 12,5 \\
\hline Police & 14,3 \\
\hline Infrastructure & 14,3 \\
\hline Taxes (general) & 15,7 \\
\hline Housing: social & 16,7 \\
\hline Spending (general) & 17,3 \\
\hline State action (other) & 21,4 \\
\hline Unemployment & 22,3 \\
\hline State action consumer & 23,3 \\
\hline Policy towards workers (general) & 24,8 \\
\hline Pension & 25,2 \\
\hline Culture \& sport & 25,3 \\
\hline State action jobs & 27,5 \\
\hline Social security (general) & 28,6 \\
\hline Work-family balance & 29,4 \\
\hline Health care & 33,2 \\
\hline Science \& technology & 33,3 \\
\hline Labour organizations & 33,3 \\
\hline Regulation prices & 41,7 \\
\hline Housing (general) & 41,7 \\
\hline Defence & 50,0 \\
\hline Education \& training & 51,5 \\
\hline Regulation (general) & \\
\hline Regulation financial sector & Regulation business \& industry \\
\hline
\end{tabular}



Table 4 and 5: Amount of quasi-sentences spent on the different categories of the coding scheme (1961-2010).

\begin{tabular}{|c|c|c|c|}
\hline \multicolumn{4}{|c|}{ Open VLD } \\
\hline & Category & $\underline{\mathrm{N}}$ & Average \% \\
\hline$\underline{1}$ & State action jobs & $\underline{392}$ & $\underline{3,50}$ \\
\hline 2 & Pension & 371 & 3,31 \\
\hline$\underline{3}$ & Health care & 362 & 3,23 \\
\hline 4 & Income taxes & 207 & 1,85 \\
\hline$\underline{5}$ & Budget deficit & 174 & 1,55 \\
\hline$\underline{6}$ & Public ownership & 157 & 1,40 \\
\hline$\underline{7}$ & Work-family balance & $\underline{156}$ & 1,39 \\
\hline 8 & Unemployment & 154 & 1,37 \\
\hline$\underline{9}$ & Education \& training & 142 & 1,27 \\
\hline 10 & Culture \& sport & 135 & 1,20 \\
\hline 11 & Payroll taxes & 119 & 1,06 \\
\hline 12 & Taxes on company profits & 109 & 0,97 \\
\hline 13 & Infrastructure & 102 & 0,91 \\
\hline 14 & State action other problems & 83 & 0,74 \\
\hline 15 & Housing: private & $\underline{64}$ & $\underline{0,57}$ \\
\hline 16 & Regulation trade & 63 & $\underline{0,56}$ \\
\hline 17 & Science \& technology & $\underline{60}$ & $\underline{0,53}$ \\
\hline 18 & Labour organizations & 59 & $\underline{0,53}$ \\
\hline 19 & Regulation prices & $\underline{48}$ & $\underline{0,43}$ \\
\hline 20 & Child support & $\underline{42}$ & 0,37 \\
\hline 21 & Defense & 38 & 0,34 \\
\hline 22 & State action consumer & 38 & 0,34 \\
\hline 23 & Sales taxes & 37 & 0,33 \\
\hline 24 & Taxes on capital (gains) & 35 & 0,31 \\
\hline 25 & Regulation fin. sector & $\underline{34}$ & $\underline{0,30}$ \\
\hline 26 & Housing: social & 26 & 0,23 \\
\hline 27 & Works council & $\underline{26}$ & $\underline{0,23}$ \\
\hline 28 & Transport & $\underline{25}$ & 0,22 \\
\hline 29 & Social security (other) & $\underline{24}$ & $\underline{0,21}$ \\
\hline 30 & Police & 20 & $\underline{0,18}$ \\
\hline 31 & Regulation business $\underline{\text { industry }}$ & $\underline{16}$ & $\underline{0,14}$ \\
\hline 32 & State action neocorporatism & 12 & 0,11 \\
\hline 33 & State action interest rates & 2 & 0,02 \\
\hline
\end{tabular}

\begin{tabular}{|c|c|c|c|}
\hline \multicolumn{4}{|c|}{ sp.a } \\
\hline & Category & $\mathrm{N}$ & Average \% \\
\hline$\underline{1}$ & Health care & 900 & $\underline{6,04}$ \\
\hline$\underline{2}$ & State action jobs & 561 & $\underline{3,76}$ \\
\hline$\underline{3}$ & State action consumer & $\underline{310}$ & $\underline{2,08}$ \\
\hline 4 & Pension & 256 & 1,72 \\
\hline$\underline{\mathbf{5}}$ & Culture \& sport & $\underline{224}$ & 1,50 \\
\hline$\underline{6}$ & Public ownership & 224 & 1,50 \\
\hline$\underline{7}$ & Work-family balance & 216 & 1,45 \\
\hline$\underline{8}$ & Transport & 175 & 1,17 \\
\hline$\underline{9}$ & Regulation business \& industry & 175 & 1,17 \\
\hline 10 & Infrastructure & 165 & 1,11 \\
\hline 11 & Regulation prices & 164 & 1,10 \\
\hline 12 & Regulation fin. sector & 158 & 1,06 \\
\hline 13 & Science \& technology & 150 & 1,01 \\
\hline 14 & Education \& training & 148 & $\underline{0,99}$ \\
\hline 15 & Housing: social & $\underline{115}$ & $\underline{0,77}$ \\
\hline 16 & Budget deficit & 108 & $\underline{0,72}$ \\
\hline 17 & State action other problems & 100 & 0,67 \\
\hline 18 & Unemployment & 90 & 0,60 \\
\hline 19 & Income taxes & 69 & $\underline{0,46}$ \\
\hline 20 & Social security (other) & 64 & $\underline{0,43}$ \\
\hline 21 & Payroll taxes & $\underline{61}$ & $\underline{0,41}$ \\
\hline 22 & Labour organizations & 61 & $\underline{0,41}$ \\
\hline 23 & Taxes on capital (gains) & $\underline{60}$ & $\underline{0,40}$ \\
\hline 24 & Taxes on company profits & 57 & $\underline{0,38}$ \\
\hline 25 & Works council & $\underline{57}$ & $\underline{0,38}$ \\
\hline 26 & Child support & $\underline{54}$ & $\underline{0,36}$ \\
\hline 27 & Housing: private & $\underline{49}$ & $\underline{0,33}$ \\
\hline 28 & Regulation trade & 47 & 0,32 \\
\hline 29 & State action neocorporatism & 46 & 0,31 \\
\hline 30 & Defense & 36 & 0,24 \\
\hline 31 & Sales taxes & 18 & $\underline{0,12}$ \\
\hline 32 & Police & 17 & $\underline{0,11}$ \\
\hline 33 & State action interest rates & $\underline{9}$ & $\underline{0,06}$ \\
\hline
\end{tabular}




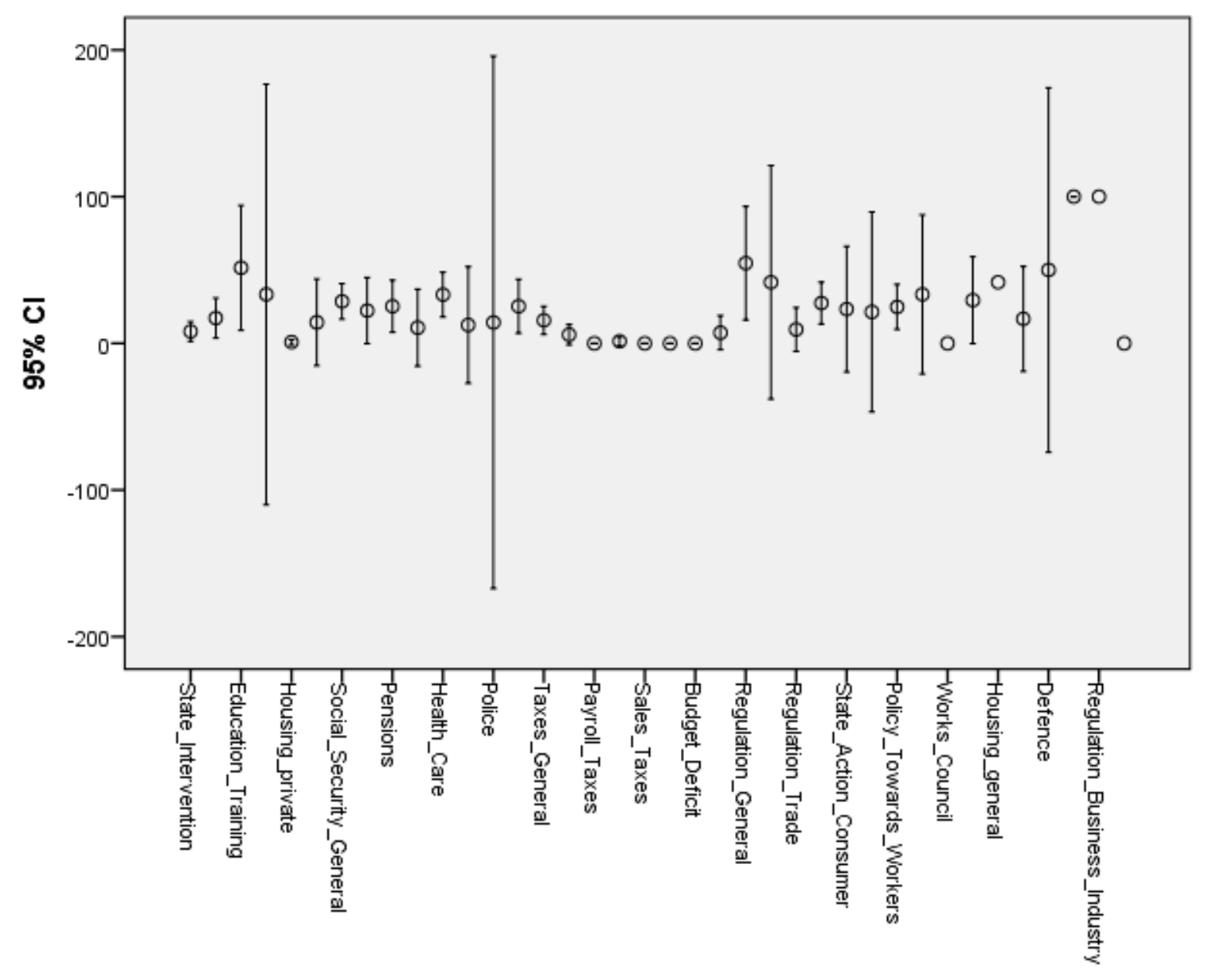


Appendix 2: Confidence intervals sp.a

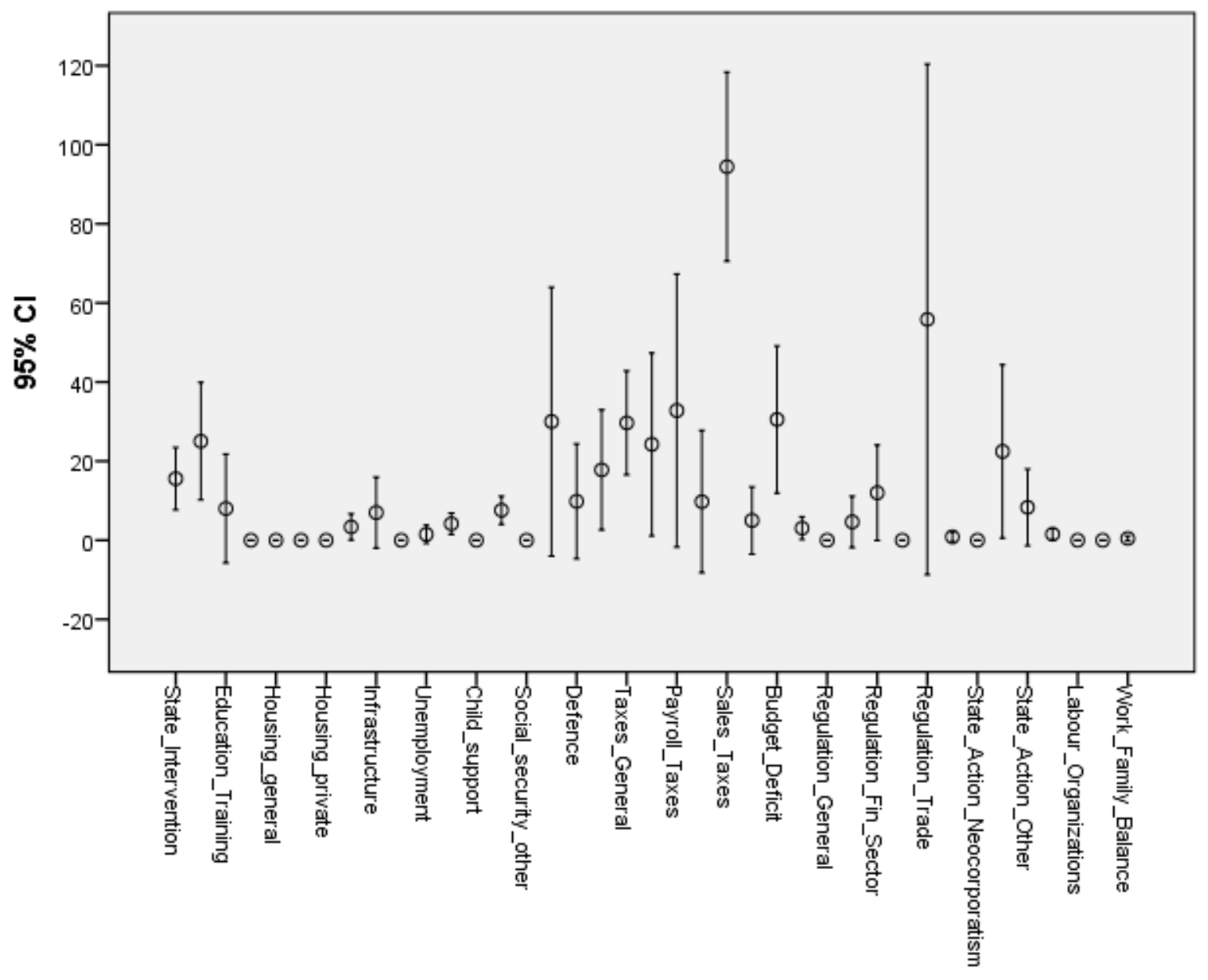

